\title{
Association of Helicobacter pylori infection with diabetes mellitus: A Meta-analysis of Case Control Studies
}

\author{
Kamyar Mansori \\ Zanjan University of Medical Sciences \\ Yousef Moradi ( $\sim$ Yousefmoradi211@yahoo.com ) \\ Iran University of Medical Sciences https://orcid.org/0000-0002-2936-5930 \\ Sara Naderpour \\ Iran University of Medical Sciences \\ Roya Rashti \\ Kurdistan University of Medical Sciences \\ Ali Baradaran Moghaddam \\ Iran University of Medical Sciences \\ Lotfolah Saed \\ Kurdistan University of Medical Sciences \\ Hedye Mohammadi \\ Kurdistan University of Medical Sciences
}

Research article

Keywords: Helicobacter pylori, Diabetes Mellitus, Type 1 Diabetes, Type 2 Diabetes, Meta-analysis

Posted Date: December 9th, 2019

DOI: https://doi.org/10.21203/rs.2.18464/v1

License: (c) (1) This work is licensed under a Creative Commons Attribution 4.0 International License. Read Full License 


\section{Abstract}

Background Results of previous studies were showed that the association between $\mathrm{H}$. pylori infection and the risk of diabetes is still controversies. Therefore, this systematic review and meta-analysis study was designed and implemented aimed to determine the association between $\mathrm{H}$. pylori infection and the risk of diabetes. Methods All case control articles were searched in international databases, including Medline (PubMed), Web of sciences, Scopus, EMBASE, and CINHAL. Search was done from January 1990 to March 2019 without language limitations. Also, logarithm and standard error logarithm odds ratio (OR) were used for meta-analysis. Results A total of 41 studies were included in this meta-analysis. The range of association with odds ratio in case control studies which published between 1990 to 2019 was 0.21 to 6.08 . The pooled estimate of the association between H. pylori infection with diabetes was 1.27 (95\% $\mathrm{Cl} 1.11$ to $1.45, \mathrm{P}=0.0001, \mathrm{I} 2=86.6 \%$ ). The effect of $\mathrm{H}$. pylori infection on diabetes mellitus, type 1 and type 2 diabetes was $1.17(95 \% \mathrm{Cl}$ 0.94 to 1.45$), 1.19$ ( $95 \% \mathrm{Cl} 0.98$ to 1.45 ), and 1.43 (95\% Cl 1.11 to 1.85 ) respectively. Subgroup analysis by the geographical regions showed in Asian population risk of the effect of $\mathrm{H}$. pylori infection on diabetes was higher than other population, but in the American, this was a protective relationship.Conclusion In conclusion, this systematic review \& meta-analysis study suggested that $\mathrm{H}$. pylori infection was associated with the risk of diabetes as compared to non- diabetes individual.

\section{Background}

Helicobacter pylori (H. pylori) is a gram-negative spiral bacterium which is found abundantly in the stomach. The H. pylori infection is one of the most common chronic infections in the world, so that more than $50 \%$ of the world's population are infected with this infection ( 1 , 2). It is now known that $\mathrm{H}$. pylori is responsible for most cases of peptic ulcer disease. Also, the different studies highlighted that it is associated with other important gastrointestinal diseases such as chronic gastritis, gastric adenocarcinoma, and MALT lymphoma which are recognized as a major public health concern in the world $(3,4)$. In addition to the role of $\mathrm{H}$. pylori in gastrointestinal disorders, some researches have suggested the potential role of this bacterium in the development of non-gastrointestinal disorders such as cardiovascular diseases and metabolic syndrome especially diabetes (5-7). Diabetes is the most common metabolic disease in the world and responsible for about 4 million deaths per year. The global prevalence of diabetes was $4.6 \%$ equivalent to 285 million in adults for 2010, which this number has reached 371 million in 2012, and is expected to reach 552 million by 2030(8-10).

As mentioned above, one of the factors that may affect incidence of diabetes is H. pylori. The relationship between H.pylori infection and diabetes was introduced in 1989 (11). It has been suggested that the $\mathrm{H}$. pylori may be contributed to the incidence of cardiovascular disease and diabetes through elevations in inflammatory cytokines levels such as C-reactive protein (CRP) and interleukin-6 (11-13). In general, various studies have investigated the role of $\mathrm{H}$. pylori in the pathogenesis of diabetes and its complications, but the results are inconsistent with each other. For example, some case-control studies have reported higher prevalence of $\mathrm{H}$. pylori in patients with diabetes $(14,15)$. Also, several cross-sectional studies have shown a significant statistical association between $\mathrm{H}$. pylori and diabetes $(3,15)$. However, some studies in this regard have shown that there is no significant association between diabetes and prevalence $\mathrm{H}$. pylori infection $(2,16,17)$.

Therefore, the association between $\mathrm{H}$. pylori infection and the risk of diabetes is still controversies. Hence, this systematic review and meta-analysis study was designed and implemented aimed to determine the association between $\mathrm{H}$. pylori infection and the risk of diabetes.

\section{Methods}

This systematic review and Meta-analysis was performed according to the Preferred reporting items for systematic reviews and metaanalyses (PRISMA) and Strengthening the Reporting of Observationally Studies in Epidemiology (STROBE) guidelines for reviews of analytical observational studies (case-control) (18-20).

\section{Search Terms and Complex Search Syntax}

All original published articles were searched in international databases, including Medline (PubMed), Web of sciences, Scopus, EMBASE, Cochrane, Ovid and CINHAL. Search was done from January 1990 to March 2019 without language limitations. The keywords were Diabetes, Diabetes Mellitus (type 1 and 2), Insulin Dependent, IDDM, NIDDM, Noninsulin Dependent, Insulin Sensitivity, Helicobacter pylori, Campylobacter pylori, and $\mathrm{H}$ Pylori. The primary search results were reviewed, and some of the articles were eliminated after reviewing their title and an abstract. Inclusion and exclusion criteria were set by 2 researchers separately (YM and RR) (Figure 1).

\section{Eligibility Criteria:}


A published study had to meet the following inclusion criteria:

(1) case-control, nested case control studies, (2) human population, (3) study population were patients with diabetes, and (4) Helicobacter pylori infection was independent variable. Case reports, reviews, animal studies, and cohort studies were removed from the tabulation. The authors resolved all disputes during the collection, compilation, and analysis of data.

\section{Data Extraction}

Two review authors (YM and RR) independently extracted and entered study data. A structured checklist was used for the extraction of information on the 1) name of first author, 2) date of publication, 3) country, 4) study subjects, 5) age of patients, 6) sample size, 7) type of diabetes, 8) mean of $\mathrm{HbA1C}$, 9) duration of diabetes, 10) measurement of association, 11) controlled variables, 12) and method of bacteria detection. Additional information on the study results was extracted with respect to the type of instruments. A data extraction form was created based on our group discussion and piloted according to 10 different types of studies. Then, it was modified and used by the data extractor. All process from systematic search to final data extraction were followed independently by two research experts (Kappa statistic for agreement for quality assessment; 0.75). Any disagreement was assessed by both and if a consensus was not reached, a third author (LS) would evaluate the study. The qualities of all studies were assessed by Modified Newcastle-Ottawa Scale for Case Control studies (21).

\section{Statistical Analysis}

Logarithm and standard error logarithm odds ratio (OR) were used for the meta-analysis. DerSimonian and Laird method was used to compute the pooled estimate of odds ratio (OR) with confidence interval ( $\mathrm{Cl} 95 \%)$ using random models (22). Because the test for heterogeneity was statistically significant in some analyses, the random effects models were used to estimate OR. In this study, $\mathrm{W}$ Cochran's Q test and I2 statistic were used to evaluate statistical heterogeneity between studies (23). In addition, a meta-regression and subgroup analysis was performed to assess the source of heterogeneity between studies. Moreover, publication bias was assessed by funnel plot and Egger test $(24,25)$. Statistical analysis was performed using STATA 14.0 (Stata Corp, College Station, TX, USA), and statistical significance was set at $p<0.05$.

\section{Results}

\section{Study Characteristics}

The first step of search in electronic databases yielded 2027 publications and 200 studies identified through other sources. In the final step, after removing the duplicates, reviewing by title, abstract and full text and considering the inclusion and exclusion criteria, 41 studies were selected for the meta-analysis of pooled association between $\mathrm{H}$. pylori infection and the risk of diabetes (Figure 1). Studies characteristics of each study included in the meta-analysis are reported in Table 1. The total sample size in the 41 studies that reported the association between $\mathrm{H}$. pylori infection and the risk of diabetes in case and control was 4445 and 5416, respectively. Also, 11 studies reported association between $\mathrm{H}$. pylori infection with DM. Other primary studies reported association between $\mathrm{H}$. pylori infection with type 1 and 2 diabetes. A total of 41 studies were included in this meta-analysis, of which 20 were conduct in European, 12 were in Asian, 7 studies done in African and 2 in American (Table 2). The range of association with odds ratio in case control studies which published between 1990 to 2019 was 0.21 to 6.08 . Of the 41 studies, 18 showed statistically significant between $\mathrm{H}$. pylori infection and the risk of diabetes.

The pooled estimate of the association between $\mathrm{H}$. pylori infection with diabetes mellitus was $1.27\left(95 \% \mathrm{Cl} 1.11\right.$ to $1.45, \mathrm{P}=0.0001, \mathrm{I}^{2}=$ $86.6 \%$ ) (Figure 2), but since the $\mathrm{Cl}$ of test (Egger's test) included zero, no significant bias occurred in the publication of the results (Egger's test $=1.579, \mathrm{P}=0.073,95 \% \mathrm{Cl}-0.154$ to 3.312 ) (Figure 3).

\section{Subgroup analysis}

Based on the random effect model, the effect of $\mathrm{H}$. pylori infection on diabetes mellitus, type 1 and type 2 diabetes was 1.17 ( $95 \% \mathrm{Cl} 0.94$ to 1.45$), 1.19$ ( $95 \% \mathrm{Cl} 0.98$ to 1.45 ), and 1.43 ( $95 \% \mathrm{Cl} 1.11$ to 1.85 ) respectively. Effect size of $\mathrm{H}$. pylori infection on type 2 diabetes was higher than type 1 and diabetes mellitus (Table 2).

Subgroup analysis by the geographical regions showed in Asian population risk of the effect of $\mathrm{H}$. pylori infection on diabetes was higher than other population, but in the American, this was a protective relationship. In addition, the relationship between $\mathrm{H}$. pylori and the risk of 
diabetes according to age showed that risk in individual with 30 to 60 year was 1.34 ( $95 \% \mathrm{Cl} 1.09,1.65)$, in 10 to 30 years, and upper 60 years was $1.34(95 \% \mathrm{Cl} 1.05,1.62)$ and $1.03(95 \% \mathrm{Cl} 0.93,3.23)$, respectively (Table 2).

Based on methods of detecting $\mathrm{H}$. pylori infection, the effect of H. pylori infection on diabetes mellitus in detect by rapid urease test was higher than other methods, but this effect not significant (Table 2).

\section{Discussion}

The purpose of this systematic review and meta-analysis study was to determine the association between $\mathrm{H}$. pylori infection and the risk of diabetes. In the present study, the range of OR for case-control studies included in meta-analysis was 0.21 to 6.08 . The results showed a significant statistical association between $\mathrm{H}$. pylori infection and the risk of diabetes (overall OR: 1.27; $95 \% \mathrm{Cl}: 1.11-1.45$ ). The results of subgroup analysis by type of diabetes revealed a significant association between $\mathrm{H}$. pylori infection and the risk of type 2 diabetes (OR: 1.43; $95 \% \mathrm{Cl}: 1.11-1.85)$, however, there was no significant relationship between H. pylori and the risk of type 1 diabetes (OR: 1.19; 95\% Cl: $0.98-1.45$ ) and diabetes mellitus (OR: $1.17 ; 95 \% \mathrm{Cl}: 0.94-1.45)$. Subgroup analysis by the geographical regions showed a significant direct relationship between $\mathrm{H}$. pylori and the risk of diabetes in Asian, Europe and Africa but in the American, this was a protective relationship. In addition, in subgroup analysis, the relationship between $\mathrm{H}$. pylori and the risk of diabetes was different according to age, level of $\mathrm{HbA1C}$, duration of diabetes and methods for $\mathrm{H}$. pylori detection. This suggests that these factors could be an important source of heterogeneity in the studies included in the meta-analysis.

Our meta-analysis suggests that $\mathrm{H}$. pylori infection can increase the risk of diabetes by up to $27 \%$. These findings are consistent with the results of several meta-analysis studies that have been done in this field. The meta-analysis study by Jun-Zhen Li et al. showed a significant statistical association between $\mathrm{H}$. pylori infection and the risk of diabetes mellitus (OR: 1.69; $95 \% \mathrm{Cl}$ : $1.47-1.95)$ and type 2 diabetes (OR: 2.05; 95\% Cl: 1.67 - 2.52), but did not show a significant relationship between risk of type 1 diabetes and $\mathrm{H}$. pylori infection (OR: $1.23 ; 95 \% \mathrm{Cl}: 0.77$ - 1.96) (2). The another study by Wang $\mathrm{F}$ et al. indicated that the H. pylori is related with an increased risk of each type of diabetes mellitus (OR: 2; 95\% Cl: $1.82-2.20$ ) also related with increased risks of type 1 (OR: 1.99; 95\% Cl: $1.52-2.60$ ) and type 2 diabetes (OR: $2.15 ; 95 \% \mathrm{Cl}: 1.81$ - 2.55) (26). Zhou et al. in meta-analysis with 41 articles and 14080 participants reveled difference significant between $\mathrm{H}$. pylori infection and increased risks of diabetes (OR: 1.33; 95\% Cl: $1.08-1.64$ ) (27). However, some studies did support significant association between $\mathrm{H}$. Pylori infection and the risk of diabetes $(16,28)$.

The Several mechanisms have been proposed for the relationship between $\mathrm{H}$. pylori infection and risk of diabetes. Inflammatory cytokine may lead to induce phosphorylation of serine residues on the insulin receptor substrate and subsequently this phenomenon may impair the interaction between the substrate and the insulin receptors due to impaired insulin function $(7,29)$. Also, Lipopolysaccharides from gram-negative bacteria such as $\mathrm{H}$. pylori may activate Toll-like receptors and subsequently insulin resistance occurs (30). All of these events can lead to reduced blood sugar control and consequently diabetes mellitus. In addition, the presence of bacterial infections can lead to microvascular failure and eventually incidence of atherosclerosis (31).

In subgroup analysis of geographical regions by the type of continent, we explored a significant direct relationship between $\mathrm{H}$. pylori and the risk of diabetes in Asian, Europe and Africa but in the American, this was a protective relationship, but there was still high heterogeneity within these subgroups. It was consistent with study of Jun-Zhen Li et al. that have shown H. pylori infection is significantly higher in diabetic patients residing in Asia and Europe than in Africa and the American (32). Also, Wang F et al. reported H. pylori can increase the risk of diabetes in European, Middle East and South Asia (26). But, study of Zhou et al. found H. pylori infection is significantly higher in diabetic patients residing in only Asia (27). This difference in various continents may be due to differences in sample size, different diagnostic methods and different medical care conditions. However, to determine the precise effect of geographical location on the association between $\mathrm{H}$. pylori and diabetes risk, it seems useful migrants study to distinguish between the role of genetic and environmental factors.

Also, in subgroup analysis, we found significant direct relationship between $\mathrm{H}$. pylori and the risk of diabetes in mean of $\mathrm{HbA} 1 \mathrm{C}>8$. This result was in line with the results of other studies in this field. For example, the study by Ming-Chia Hsieh et al. displayed patients with higher levels of $\mathrm{HbA} 1 \mathrm{c}$ had higher prevalence of $\mathrm{H}$. pylori infection than patients with lower levels of $\mathrm{HbA} 1 \mathrm{c}$ and this association was significant statistically (33). Another study in China revealed individuals with $\mathrm{H}$. pylori infection had a higher level $\mathrm{HbA} 1 \mathrm{C}$ than those who did not (34). Considering the $\mathrm{HbA1} \mathrm{c}$ is a valid and reliable indicator for estimating average blood sugar in long-term, it seems to be more valid to evaluate the effect of chronic $\mathrm{H}$. pylori infection on blood glucose regulation (35-37). So, pay attention to HbA1c in assessing the relationship between $\mathrm{H}$. pylori and the risk of diabetes can be important, although there was still high heterogeneity within these subgroups in our study. In addition, in subgroup analysis relationship between $\mathrm{H}$. pylori and the risk of diabetes was different by age. This 
finding was consistent with results of other studies, because the different studies have shown that the prevalence of $\mathrm{H}$. pylori infection varies with age (38).

Finally, association between H. pylori and the risk of diabetes was different by methods for $\mathrm{H}$. pylori detection in subgroup analysis. This suggests that this factor could be an important source of heterogeneity in the studies included in the meta-analysis, because different methods of detection for $\mathrm{H}$. pylori have different accuracy and precision. The studies have shown that the serological tests of anti- $\mathrm{H}$. Pylori IgG or/and IgA antibody in serum may be report many false positives $(39,40)$. As a results, association $\mathrm{H}$. pylori and the risk of diabetes may be different according to the method of diagnosis of infection.

\section{Strengths And Limitations}

This study also has several limitation and strengths. The first strength of this study is deal with heterogeneity through a subgroups analysis based on Type of diabetes, geographical regions, age, and level of HbA1C, duration of diabetes and methods for $\mathrm{H}$. pylori detection. Another strength was considerable number of studies included in the meta-analysis ( $41 \mathrm{study}$ ) that would be possible to investigate the exact effect of the publication bias on the results. Also, this study has several limitations. Firstly, missing potential studies e.g. limiting full- text review to English language articles may be lead to some degree of selection bias. Secondly, all studies included in meta-analysis were case-control, hence, the design and implementation of cohort studies are essential for detailed assessment of the association between $\mathrm{H}$. pylori infection and diabetes. Thirdly, personal judgments may be effect on search of articles, data extraction and assessment of included articles in meta-analysis.

\section{Conclusions}

In conclusion, this systematic review \& meta-analysis study suggested that $\mathrm{H}$. pylori infection was associated with the risk of diabetes as compared to non- diabetes individual. However, in subgroup analysis by type of diabetes, this association was only significant for type 2 diabetes.

\section{Abbreviations}

Cl: Confidence Interval

OR: Odds Ratio

IDDM: Insulin-Dependent Diabetes Mellitus

NIDDM: Non-Insulin-Dependent Diabetes Mellitus

CINAHL: Cumulative Index to Nursing and Allied Health Literature

EMBASE: Excerpta Medica dataBASE

STROBE: Strengthening the Reporting of Observationally Studies in Epidemiology

PRISMA: Preferred reporting items for systematic reviews and meta-analyses

H. pylori: Helicobacter Pylori

\section{Declarations}

\section{Ethics approval and consent to participate}

Not applicable.

\section{Consent for Publication}

Not applicable.

\section{Availability of Data and Material}


Input data for the analyses are available from the corresponding author on request.

\section{Competing Interests}

The authors declare that they have no competing interests.

\section{Funding}

This research did not receive any specific grant from funding agencies in the public, commercial, or not-for-profit sectors.

\section{Authors' Contributions}

YM conceptualized the idea for this review, formulated the review question, and objectives, assisted with the development of the final search strategy, contributed to the data analysis/ interpretation, and writing the manuscript. KM, SN, LS, HM and RR contributed to the conceptualization of the final review question, formulation of the review objectives, data analysis/interpretation, and writing the manuscript. HM, LS, and ABM contributed to the conducting the searches, data extraction and data analysis/interpretation. All authors read and approved the final manuscript.

\section{Acknowledgements}

Not applicable.

\section{References}

1. Ozen A, Furman A, Berber M, Karatepe HO, Mutlu N, Sarıçoban HE, et al. The effect of Helicobacter pylori and economic status on growth parameters and leptin, ghrelin, and insulin-like growth factor (IGF)-I concentrations in children. Helicobacter. 2011;16(1):5565.

2. Li J-Z, Li J-Y, Wu T-F, Xu J-H, Huang C-Z, Cheng D, et al. Helicobacter pylori infection is associated with type 2 diabetes, not type 1 diabetes: an updated meta-analysis. Gastroenterology research and practice. 2017;2017.

3. Bajaj S, Rekwal L, Misra S, Misra V, Yadav RK, Srivastava A. Association of helicobacter pylori infection with type 2 diabetes. Indian journal of endocrinology and metabolism. 2014;18(5):694.

4. Gulcelik N, Kaya E, Demirbas B, Culha C, Koc G, Ozkaya M, et al. Helicobacter pylori prevalence in diabetic patients and its relationship with dyspepsia and autonomic neuropathy. Journal of endocrinological investigation. 2005;28(5):214-7.

5. Georges J-L, Rupprecht HJ, Blankenberg S, Poirier O, Bickel C, Hafner G, et al. Impact of pathogen burden in patients with coronary artery disease in relation to systemic inflammation and variation in genes encoding cytokines. The American journal of cardiology. 2003;92(5):515-21.

6. Simanek AM, Dowd JB, Aiello AE. Persistent pathogens linking socioeconomic position and cardiovascular disease in the US. International journal of epidemiology. 2008;38(3):775-87.

7. Wellen KE, Hotamisligil GS. Inflammation, stress, and diabetes. The Journal of clinical investigation. 2005;115(5):1111-9.

8. Shaw JE, Sicree RA, Zimmet PZ. Global estimates of the prevalence of diabetes for 2010 and 2030. Diabetes research and clinical practice. 2010;87(1):4-14.

9. Rathmann W, Giani G. Global Prevalence of Diabetes: Estimates for the Year 2000 and Projections for 2030: Response to Wild et al. Diabetes care. 2004;27(10):2568-9.

10. Wild S, Roglic G, Green A, Sicree R, King H. Global prevalence of diabetes: estimates for the year 2000 and projections for 2030. Diabetes care. 2004;27(5):1047-53.

11. Simon L, Tornóczky J, Toth M, Jámbor M, Sudár Z. The significance of Campylobacter pylori infection in gastroenterologic and diabetic practice. Orvosi hetilap. 1989;130(25):1325-9.

12. Oldenburg B, Diepersloot R, Hoekstra J. High seroprevalence ofHelicobacter pylori in diabetes mellitus patients. Digestive diseases and sciences. 1996;41(3):458-61.

13. Papamichael KX, Papaioannou G, Karga H, Roussos A, Mantzaris GJ. Helicobacter pylori infection and endocrine disorders: is there a link? World journal of gastroenterology: WJG. 2009;15(22):2701.

14. Kayar Y, Pamukçu Ö, Eroğlu H, Kalkan Erol K, Ilhan A, Kocaman O. Relationship between Helicobacter pylori infections in diabetic patients and inflammations, metabolic syndrome, and complications. International journal of chronic diseases. 2015;2015. 
15. Devrajani BR, Shah SZA, Soomro AA, Devrajani T. Type 2 diabetes mellitus: A risk factor for Helicobacter pylori infection: A hospital based case-control study. International journal of diabetes in developing countries. 2010;30(1):22.

16. Anastasios R, Goritsas C, Papamihail C, Trigidou R, Garzonis P, Ferti A. Helicobacter pylori infection in diabetic patients: prevalence and endoscopic findings. European journal of internal medicine. 2002;13(6):376-9.

17. Zhou F, Zhong X, Chen J, Li C, Shang M, Jiang C, et al. Helicobacter pylori infection associated with type 2 diabetic nephropathy in patients with dyspeptic symptoms. Diabetes research and clinical practice. 2015;110(3):328-34.

18. Knottnerus A, Tugwell P. STROBE-a checklist to Strengthen the Reporting of Observational Studies in Epidemiology. Pergamon; 2008.

19. Stroup DF, Berlin JA, Morton SC, Olkin I, Williamson GD, Rennie D, et al. Meta-analysis of observational studies in epidemiology: a proposal for reporting. Jama. 2000;283(15):2008-12.

20. Moher D, Liberati A, Tetzlaff J, Altman DG. Preferred reporting items for systematic reviews and meta-analyses: the PRISMA statement. Annals of internal medicine. 2009;151(4):264-9..

21. Margulis AV, Pladevall M, Riera-Guardia N, Varas-Lorenzo C, Hazell L, Berkman ND, et al. Quality assessment of observational studies in a drug-safety systematic review, comparison of two tools: the Newcastle-Ottawa scale and the RTI item bank. Clinical epidemiology. 2014;6:359.

22. DerSimonian R, Laird N. Meta-analysis in clinical trials. Controlled clinical trials. 1986;7(3):177-88.

23. Higgins J, Thompson SG. Quantifying heterogeneity in a meta-analysis. Statistics in medicine. 2002;21(11):1539-58.

24. Egger M, Smith GD, Minder C. Bias in meta-analysis detected by a simple, graphical test. British Medical Journal. 1998;316(7129):470-1.

25. Egger M, Smith GD, Schneider M, Minder C. Bias in meta-analysis detected by a simple, graphical test. Bmj. 1997;315(7109):629-34.

26. Wang F, Liu J, Lv Z. Association of Helicobacter pylori infection with diabetes mellitus and diabetic nephropathy: a meta-analysis of 39 studies involving more than 20,000 participants. Scandinavian journal of infectious diseases. 2013;45(12):930-8.

27. Zhou X, Zhang C, Wu J, Zhang G. Association between Helicobacter pylori infection and diabetes mellitus: a meta-analysis of observational studies. Diabetes Research and Clinical Practice. 2013;99(2):200-8.

28. Woodward M, Morrison C, McColl K. An investigation into factors associated with Helicobacter pylori infection. Journal of clinical epidemiology. 2000;53(2):175-81.

29. Pradhan AD, Manson JE, Rifai N, Buring JE, Ridker PM. C-reactive protein, interleukin 6, and risk of developing type 2 diabetes mellitus. Jama. 2001;286(3):327-34.

30. Manco M, Putignani L, Bottazzo GF. Gut microbiota, lipopolysaccharides, and innate immunity in the pathogenesis of obesity and cardiovascular risk. Endocrine reviews. 2010;31(6):817-44.

31. Crabtree J, Shallcross T, Heatley R, Wyatt J. Mucosal tumour necrosis factor alpha and interleukin-6 in patients with Helicobacter pylori associated gastritis. Gut. 1991;32(12):1473-7.

32. Yang YJ, Wu CT, Ou HY, Lin CH, Cheng HC, Chang WL, et al. Male non-insulin users with type 2 diabetes mellitus are predisposed to gastric corpus-predominant inflammation after H. pylori infection. Journal of Biomedical Science. 2017;24(1).

33. Hsieh MC, Wang SS, Hsieh YT, Kuo FC, Soon MS, Wu DC. H elicobacter pylori infection associated with high H b A 1c and type 2 diabetes. European journal of clinical investigation. 2013;43(9):949-56.

34. Han X, Li Y, Wang J, Liu B, Hu H, Li X, et al. Helicobacter pylori infection is associated with type 2 diabetes among a middle-and oldage Chinese population. Diabetes/metabolism research and reviews. 2016;32(1):95-101.

35. Chen Y, Blaser MJ. Association between gastric Helicobacter pylori colonization and glycated hemoglobin levels. Journal of Infectious Diseases. 2012;205(8):1195-202.

36. Buell C, Kermah D, Davidson MB. Utility of A1C for diabetes screening in the 1999-2004 NHANES population. Diabetes care. 2007;30(9):2233-5.

37. Rohlfing C, Little R, Wiedmeyer H, England J, Goldstein D. Use of GHb (HbA (1c)) to screen for undiagnosed diabetes in the US population-Response. Diabetes Care. 2000;23(8):1208-.

38. Eshraghian A, Hashemi SA, Jahromi AH, Eshraghian H, Masoompour SM, Davarpanah MA, et al. Helicobacter pylori infection as a risk factor for insulin resistance. Digestive diseases and sciences. 2009;54(9):1966-70.

39. Miftahussurur M, Yamaoka Y. Diagnostic methods of Helicobacter pylori infection for epidemiological studies: critical importance of indirect test validation. BioMed research international. 2016;2016.

Page 7/16 
40. Tonkic A, Vukovic J, Cindro PV, Pisac VP, Tonkic M. Diagnosis of Helicobacter pylori infection. Wiener klinische Wochenschrift. 2018;130(17-18):530-4.

41. Małecki M, Bień A, Galicka-Latała D, Stachura J, Sieradzki J. The prevalence of Helicobacter pylori infection and types of gastritis in diabetic patients. The Krakow study. Experimental and clinical endocrinology \& diabetes. 1996;104(05):365-9.

42. Pocecco M, Buratti E, Tommasini A, Torre G, Not T. High risk of Helicobacter pylori infection associated with cow's milk antibodies in young diabetics. Acta paediatrica (Oslo, Norway : 1992). 1997;86(7):700-3.

43. Gentile S, Turco S, Oliviero B, Torella R. The role of autonomic neuropathy as a risk factor of Helicobacter pylori infection in dyspeptic patients with type 2 diabetes mellitus. Diabetes Res Clin Pract. 1998;42(1):41-8.

44. De Luis D, De La Calle H, Roy G, De Argila CM, Valdezate S, Canton R, et al. Helicobacter pylori infection and insulin-dependent diabetes mellitus. Diabetes research and clinical practice. 1998;39(2):143-6.

45. Gasbarrini A, Ojetti V, Pitocco D, De Luca A, Franceschi F, Candelli M, et al. Helicobacter pylori infection in patients affected by insulindependent diabetes mellitus. European journal of gastroenterology \& hepatology. 1998;10(6):469-72.

46. Salardi S, Cacciari E, Menegatti M, Landi F, Mazzanti L, Stella FA, et al. Helicobacter pylori and type 1 diabetes mellitus in children. Journal of pediatric gastroenterology and nutrition. 1999;28(3):307-9.

47. Arslan D, Kendirci M, Kurtoglu S, Kula M. Helicobacter pylori infection in children with insulin dependent diabetes mellitus. Journal of Pediatric Endocrinology and Metabolism. 2000;13(5):553-6.

48. Dore MP, Bilotta M, Malaty HM, Pacifico A, Maioli M, Graham DY, et al. Diabetes mellitus and Helicobacter pylori infection. Nutrition. 2000;16(6):407-10.

49. Senturk O, Canturk Z, Cetinarslan B, Ercin C, Hulagu S, Canturk NZ. Prevalence and comparisons of five different diagnostic methods for Helicobacter pylori in diabetic patients. Endocrine research. 2001;27(1-2):179-89.

50. Ravera M, Bahenda S, Owor R, Visona R. Helicobacter pylori infection in diabetic patients with dyspepsia in Uganda. Digestive and liver disease : official journal of the Italian Society of Gastroenterology and the Italian Association for the Study of the Liver. 2001;33(4):390-1.

51. Ko GT, Chan FK, Chan WB, Sung JJ, Tsoi CL, To KF, et al. Helicobacter pylori infection in Chinese subjects with type 2 diabetes. Endocrine research. 2001;27(1-2):171-7.

52. M. M, G. L, D. M, E. S, R. I, P. S, et al. Increased prevalence of Helicobacter pyhri

in patients with diabetes mellitus. Digestive and Liver Disease. 2001;33(1):21-9.

53. Quatrini M, Boarino V, Ghidoni A, Baldassarri AR, Bianchi PA, Bardella MT. Helicobacter pylori prevalence in patients with diabetes and its relationship to dyspeptic symptoms. Journal of clinical gastroenterology. 2001;32(3):215-7.

54. Cenerelli S, Bonazzi P, Galeazzi R, Testa I, Bonfigli AR, Sirolla C, et al. Helicobacter pylori masks differences in homocysteine plasma levels between controls and type 2 diabetic patients. European Journal of Clinical Investigation. 2002;32(3):158-62.

55. Maule S, Lombardo L, Rossi C, Crocella L, Masoero G, Della Monica P, et al. Helicobacter pylori infection and gastric function in primary autonomic neuropathy. Clinical autonomic research : official journal of the Clinical Autonomic Research Society. 2002;12(3):193-6.

56. Candelli M, Rigante D, Marietti G, Nista EC, Crea F, Bartolozzi F, et al. Helicobacter pylori, gastrointestinal symptoms, and metabolic control in young type 1 diabetes mellitus patients. Pediatrics. 2003;111(4):800-3.

57. Gulcelik NE, Kaya E, Demirbas B, Culha C, Koc G, Ozkaya M, et al. Helicobacter pylori prevalence in diabetic patients and its relationship with dyspepsia and autonomic neuropathy. Journal of endocrinological investigation. 2005;28(3):214-7.

58. Jaber SM. Helicobacter pylori seropositivity in children with chronic disease in Jeddah, Saudi Arabia. Saudi journal of gastroenterology : official journal of the Saudi Gastroenterology Association. 2006;12(1):21-6.

59. Bener A, Micallef R, Afifi M, Derbala M, Al-Mulla HM, Usmani MA. Association between type 2 diabetes mellitus and Helicobacter pylori infection. Turkish Journal of Gastroenterology. 2007;18(4):225-9.

60. Demir M, Gokturk HS, Ozturk NA, Kulaksizoglu M, Serin E, Yilmaz U. Helicobacter pylori prevalence in diabetes mellitus patients with dyspeptic symptoms and its relationship to glycemic control and late complications. Digestive diseases and sciences. 2008;53(10):2646-9.

61. Ariizumi K, Koike T, Ohara S, Inomata Y, Abe Y, lijima K, et al. Incidence of reflux esophagitis and $\mathrm{H}$ pylori infection in diabetic patients. World journal of gastroenterology. 2008;14(20):3212-7. 
62. Hamed SA, Amine NF, Galal GM, Helal SR, Tag El-Din LM, Shawky OA, et al. Vascular risks and complications in diabetes mellitus: the role of helicobacter pylori infection. Journal of stroke and cerebrovascular diseases : the official journal of National Stroke Association. 2008;17(2):86-94.

63. Cabral VLR, Patrício FRDS, Gabbay MAL, Dib SA, Miszputen SJ. Intraepithelial lymphocytes in duodenum from Brazilian adolescents with type 1 diabetes. Influence of Helicobacter pylori. Pediatric Diabetes. 2009;10(5):316-20.

64. Lazaraki G, Kountouras J, Metallidis S, Vrettou E, Alevizos M, Tzioufa V, et al. Endothelial nitric oxide synthase (eNOS) is not upregulated in gastric mucosa of Helicobacter pylori $(\mathrm{H}$. pylori)-positive patients with type 2 diabetes mellitus. Digestive and liver disease : official journal of the Italian Society of Gastroenterology and the Italian Association for the Study of the Liver. 2009;41(4):253-62.

65. Krause I, Anaya JM, Fraser A, Barzilai O, Ram M, Abad V, et al. Anti-infectious antibodies and autoimmune-associated autoantibodies in patients with type I diabetes mellitus and their close family members. Annals of the New York Academy of Sciences. 2009;1173:633-9.

66. Devrajani BR, Shah SZ, Soomro AA, Devrajani T. Type 2 diabetes mellitus: A risk factor for Helicobacter pylori infection: A hospital based case-control study. International journal of diabetes in developing countries. 2010;30(1):22-6.

67. Ibrahim A, Zaher T, Ghonemy TA, El-Azim SA, El-Azim MA, Ramadan A. Impact of cytotoxin-associated gene A of Helicobacter pylori strains on microalbuminuria in type 2 diabetes. Saudi journal of kidney diseases and transplantation : an official publication of the Saudi Center for Organ Transplantation, Saudi Arabia. 2010;21(4):694-700.

68. El-Eshmawy MM, El-Hawary AK, Abdel Gawad SS, El-Baiomy AA. Helicobacter pylori infection might be responsible for the interconnection between type 1 diabetes and autoimmune thyroiditis. Diabetology and Metabolic Syndrome. 2011;3(1).

69. De Block CEM, De Leeuw IH, Bogers J, Pelckmans PA, leven MM, Van Marck EAE, et al. Helicobacter pylori, parietal cell antibodies and autoimmune gastropathy in type 1 diabetes mellitus. Alimentary Pharmacology \& Therapeutics. 2002;16(2):281-9.

70. Candelli M, Rigante D, Schiavino A, Gabrielli M, Crea F, Del Lungo LM, et al. High reinfection rate of Helicobacter pylori in young type 1 diabetic patients: a three-year follow-up study. Age (years). 2012;19(4.3):19.8-4.3.

71. Jafarzadeh A, Rezayati MT, Nemati M. Helicobacter pylori seropositivity in patients with type 2 diabetes mellitus in south-east of Iran. Acta medica Iranica. 2013;51(12):892-6.

72. Keramat F, Hashemi SH, Majlesi A, Haddadinejad S, Esfehani AM, Poorolajal J. The association between diabetes mellitus and Helicobacter pylori infection. International Journal of Diabetes in Developing Countries. 2013;33(3):155-60.

73. Zekry OA, Abd Elwahid HA. The association between Helicobacter pylori infection, type 1 diabetes mellitus, and autoimmune thyroiditis. The Journal of the Egyptian Public Health Association. 2013;88(3):143-7.

74. Chobot A, Bak-Drabik K, Skala-Zamorowska E, Krzywicka A, Kwiecien J, Polanska J. Helicobacter pylori infection in type 1 diabetes children and adolescents using 13C urea breath test. Polish journal of microbiology. 2014;63(1):63-7.

75. Fayed SB, Abd El Dayem SM, Khalil E, Abd El Kader M, Abd El Halim E. Helicobacter pylori infection in children with type 1 diabetes mellitus. Macedonian Journal of Medical Sciences. 2014;7(1):114-8.

76. Bazmamoun H, Rafeey M, Nikpouri M, Ghergherehchi R. Helicobacter pylori infection in children with type 1 diabetes mellitus: A casecontrol study. Journal of Research in Health Sciences. 2016;16(2):68-71.

77. Osman SM, Mubarak SM, Omer IM, Abdullah MA. Helicobacter pylori infection and the onset of type 1 diabetes mellitus in Sudanese children. Sudanese journal of paediatrics. 2016;16(2):59-66.

78. Alzahrani S, Nelson J, Moss SF, Paulus JK, Knowler WC, Pittas AG. H. pylori seroprevalence and risk of diabetes: An ancillary casecontrol study nested in the diabetes prevention program. Journal of Diabetes and its Complications. 2017;31(10):1515-20.

79. Vaishnav B, Shaikh S, Bamanikar A, Kakrani A, Tambile R. Diagnostic upper gastrointestinal endoscopy and prevalence of $<i>$ Helicobacter Pylori</i> infection in dyspeptic type 2 diabetes mellitus patients. Journal of Digestive Endoscopy. 2018;9(2):53-60.

\section{Tables}

Table 1: The main characteristics of Case - Control studies of the effect of $\mathrm{H}$ pylori on risk of diabetes 


\begin{tabular}{|c|c|c|c|c|c|c|c|c|c|c|}
\hline Authors & Years & Country & $\begin{array}{c}\text { Control subjects } \\
\text { (selection } \\
\text { methods) }\end{array}$ & Age & Sample size & $\begin{array}{c}\text { Type of } \\
\text { Diabetic } \\
\text { (Mean } \\
\text { HbA1C) } \\
\text { (Duration } \\
\text { of disease) }\end{array}$ & $\begin{array}{c}\text { Measurement } \\
\text { of association } \\
\text { Odds Ratio } \\
\text { (CI 95\%) }\end{array}$ & $\begin{array}{c}\text { Controlled } \\
\text { variables }\end{array}$ & $\begin{array}{c}\text { Bacteria } \\
\text { detection }\end{array}$ & $\begin{array}{l}\text { NOS } \\
\text { Score }\end{array}$ \\
\hline $\begin{array}{l}\text { Małecki, M. } \\
\text { et al(41) }\end{array}$ & 1996 & Poland & $\begin{array}{c}\text { Non-diabetic } \\
\text { subjects }\end{array}$ & $17-80$ & $\begin{array}{c}139 \\
\text { (Control:100 } \\
\text { \& Case: } 39 \text { ) }\end{array}$ & $\begin{array}{c}\text { DM (-) } \\
\text { (8 Year) }\end{array}$ & $\begin{array}{c}0.33 \\
(0.18,0.59)\end{array}$ & - & $\begin{array}{l}\text { Histology } \\
\text { or biopsy }\end{array}$ & 6 \\
\hline $\begin{array}{c}\text { Pocecco, M. } \\
\text { et al(42) }\end{array}$ & 1997 & Italy & $\begin{array}{c}\text { Admitted for } \\
\text { minor } \\
\text { extra-abdominal } \\
\text { surgery with no } \\
\text { history of } \\
\text { abdominal } \\
\text { pain }\end{array}$ & 16 & $\begin{array}{c}379 \\
\text { [Control:310 } \\
\text { \& Case: 69] }\end{array}$ & $\begin{array}{l}\text { DM } \\
(-) \\
(-)\end{array}$ & $\begin{array}{c}3.13 \\
(2.08,4.70)\end{array}$ & $\begin{array}{c}\text { Age, sex, } \\
\text { education and } \\
\text { economic }\end{array}$ & $\begin{array}{c}\text { Rapid } \\
\text { urease } \\
\text { test }\end{array}$ & 6 \\
\hline $\begin{array}{l}\text { Gentile, S. } \\
\text { (43) }\end{array}$ & 1998 & Italy & $\begin{array}{l}\text { Non-diabetic } \\
\text { subjects }\end{array}$ & 52 & $\begin{array}{c}328 \\
\text { (Control:164 } \\
\text { \& Case: } \\
164)\end{array}$ & $\begin{array}{c}\text { T2DM } \\
(8.3 \pm 1.4)\end{array}$ & $\begin{array}{c}1.77 \\
(1.35,2.31)\end{array}$ & $\begin{array}{l}\text { Age, sex and } \\
\text { body weight }\end{array}$ & $\begin{array}{l}\text { Histology } \\
\text { or biopsy }\end{array}$ & 7 \\
\hline $\begin{array}{l}\text { De Luis, } \\
\text { DA(44) }\end{array}$ & 1998 & Spain & $\begin{array}{c}\text { The control } \\
\text { subjects were } \\
\text { healthy } \\
\text { volunteers, with } \\
\text { similar age and } \\
\text { sex-distribution } \\
\text { that the diabetic } \\
\text { patients }\end{array}$ & 25 & $\begin{array}{c}180 \\
\text { Control: } 100 \\
\text { \& Case: } 80\end{array}$ & $\begin{array}{c}\text { T1DM (-) } \\
(3.1 \\
\text { Year) }\end{array}$ & $\begin{array}{c}1.36 \\
(0.98,1.87)\end{array}$ & Age and sex & $\begin{array}{l}\text { Anti-H. } \\
\text { pylori } \\
\text { antibody }\end{array}$ & 6 \\
\hline $\begin{array}{l}\text { Gasbarrini, } \\
\text { A.et al(45) }\end{array}$ & 1998 & Italy & $\begin{array}{l}\text { Healthy } \\
\text { subjects }\end{array}$ & 35 & $\begin{array}{c}166 \\
\text { [Control: } 50 \\
\text { \& Case: } \\
116]\end{array}$ & $\begin{array}{c}\text { DM } \\
(-) \\
(19 \text { year })\end{array}$ & $\begin{array}{c}1.04 \\
(0.85,1.28)\end{array}$ & Age and sex & $\begin{array}{c}13 \mathrm{C} \text { or } \\
14 \mathrm{C} \text { urea } \\
\text { breath } \\
\text { test }\end{array}$ & 6 \\
\hline $\begin{array}{c}\text { Salardi, S.et } \\
\text { al(46) }\end{array}$ & 1999 & Italy & $\begin{array}{c}\text { Children with } \\
\text { minor endocrine } \\
\text { disorders. }\end{array}$ & 12 & $\begin{array}{c}339 \\
\text { [Control: } \\
236 \text { \& Case: } \\
103]\end{array}$ & $\begin{array}{c}\text { T1DM } \\
(-) \\
(-)\end{array}$ & $\begin{array}{c}1.47 \\
(0.99,2.18)\end{array}$ & Age & $\begin{array}{l}\text { Anti H. } \\
\text { pylori } \\
\text { antibody }\end{array}$ & 7 \\
\hline $\begin{array}{l}\text { Arslan, D. et } \\
\text { al(47) }\end{array}$ & 2000 & Turkey & $\begin{array}{l}\text { Non-diabetic } \\
\text { subjects }\end{array}$ & 12 & $\begin{array}{c}130 \\
\text { (Control: } 42 \\
\text { \& Case: } 88 \text { ) }\end{array}$ & $\begin{array}{c}\text { T1DM } \\
(11.08 \pm \\
3.17) \\
(3.85 \text { Year) }\end{array}$ & $\begin{array}{c}1.38 \\
(1.08,1.75)\end{array}$ & - & $\begin{array}{l}\text { Anti-H. } \\
\text { pylori } \\
\text { antibody }\end{array}$ & 6 \\
\hline $\begin{array}{c}\text { Dore, MP. et } \\
\text { al (48) }\end{array}$ & 2000 & Italy & $\begin{array}{l}\text { Blood donors } \\
\text { from the same } \\
\text { geographic area }\end{array}$ & $12-75$ & $\begin{array}{c}891 \\
\text { [Control: } \\
506 \text { \& Case: } \\
385]\end{array}$ & $\begin{array}{c}\text { DM } \\
\text { (greater } \\
\text { than } 1 \\
\text { year) }\end{array}$ & $\begin{array}{c}1.16 \\
(1.00,1.35)\end{array}$ & $\begin{array}{c}\text { age and } \\
\text { socioeconomic } \\
\text { status }\end{array}$ & $\begin{array}{l}\text { Anti-H. } \\
\text { pylori } \\
\text { antibody }\end{array}$ & 8 \\
\hline $\begin{array}{c}\text { Senturk, O. } \\
\text { et al } \\
\text { (49) }\end{array}$ & 2001 & Turkey & $\begin{array}{c}\text { Nondiabetic } \\
\text { patients } \\
\text { undergoing } \\
\text { upper diagnostic } \\
\text { endoscopies }\end{array}$ & 54.1 & $\begin{array}{c}140 \\
\text { [Control: } 73 \\
\text { \& Case: 67] }\end{array}$ & $\begin{array}{c}\text { T2DM } \\
(6.42 \pm \\
0.97) \\
(4.5 \text { year })\end{array}$ & $\begin{array}{c}1.39 \\
(0.78,2.48)\end{array}$ & $\begin{array}{c}\text { Age and } \\
\text { socioeconomic }\end{array}$ & $\begin{array}{l}\text { Histology } \\
\text { or biopsy }\end{array}$ & 7 \\
\hline $\begin{array}{c}\text { Ravera, M.et } \\
\text { al(50) }\end{array}$ & 2001 & Uganda & $\begin{array}{c}\text { Dyspeptic } \\
\text { patients without } \\
\text { diabetic }\end{array}$ & - & $\begin{array}{c}132 \\
\text { [Control110: } \\
\text { \& Case: 22] }\end{array}$ & $\begin{array}{l}\text { DM } \\
(-) \\
(-)\end{array}$ & $\begin{array}{c}1.22 \\
(0.33,4.49)\end{array}$ & - & $\begin{array}{l}\text { Histology } \\
\text { or biopsy }\end{array}$ & 6 \\
\hline $\begin{array}{l}\text { Ko, G. T.et } \\
\text { al (51) }\end{array}$ & 2001 & Chine & $\begin{array}{l}\text { With upper GI } \\
\text { symptoms in } \\
\text { whom }\end{array}$ & 49.9 & $\begin{array}{c}118 \\
\text { [Control55: } \\
\text { \& Case: 63] }\end{array}$ & $\begin{array}{c}\text { T2DM } \\
(8.25 \pm 2.22 \\
)(6.2 \text { year }) \\
\end{array}$ & $\begin{array}{c}0.90 \\
(0.64,1.26)\end{array}$ & Age and sex & $\begin{array}{c}\text { Rapid } \\
\text { urease } \\
\text { test }\end{array}$ & 6 \\
\hline $\begin{array}{c}\text { Marrollo } \\
\text { M.et al(52) }\end{array}$ & 2001 & Italy & $\begin{array}{l}\text { Non diabetic } \\
\text { dyspeptic } \\
\text { patients }\end{array}$ & 63 & $\begin{array}{c}191 \\
\text { [Control: } \\
\text { 117\& Case: } \\
74]\end{array}$ & $\begin{array}{l}\text { DM } \\
(-) \\
(-)\end{array}$ & $\begin{array}{c}1.54 \\
(1.05,2.27)\end{array}$ & Age and sex & $\begin{array}{c}\text { Rapid } \\
\text { urease } \\
\text { test and } \\
\text { Histology } \\
\text { or biopsy }\end{array}$ & 6 \\
\hline $\begin{array}{c}\text { Quatrini, } \\
\text { M.et al (53) }\end{array}$ & 2001 & Italy & $\begin{array}{l}\text { Dyspepsia } \\
\text { patients }\end{array}$ & 58 & $\begin{array}{c}142 \\
\text { [Control: } 71 \\
\text { \& Case: } 71]\end{array}$ & $\begin{array}{l}\text { DM } \\
(-) \\
(-)\end{array}$ & $\begin{array}{c}1.63 \\
(1.12,2.38)\end{array}$ & Age and sex & $\begin{array}{c}\text { 13C or } \\
14 \mathrm{C} \text { urea }\end{array}$ & 7 \\
\hline
\end{tabular}




\begin{tabular}{|c|c|c|c|c|c|c|c|c|c|c|}
\hline & & & & & & & & & $\begin{array}{l}\text { breath } \\
\text { test }\end{array}$ & \\
\hline $\begin{array}{l}\text { Cenerelli, S. } \\
\text { et al( } 54)\end{array}$ & 2002 & Italy & $\begin{array}{l}\text { Control subjects } \\
\text { were } \\
\text { first selected on } \\
\text { the basis of the } \\
\text { admission } \\
\text { criteria of the } \\
\text { senieur protocol. }\end{array}$ & 55 & $\begin{array}{c}73 \\
\text { Control: } 43 \\
\text { \& Case: } 30 \text { ) }\end{array}$ & $\begin{array}{c}\text { T2DM }(6.1 \\
\pm 1.8) \\
(3.1 \\
\text { Year })\end{array}$ & $\begin{array}{c}1.04 \\
(0.60,1.80)\end{array}$ & - & $\begin{array}{l}\text { 13C or } \\
\text { 14C urea } \\
\text { breath } \\
\text { test }\end{array}$ & 7 \\
\hline $\begin{array}{l}\text { Maule, S.et } \\
\text { al (55) }\end{array}$ & 2002 & Italy & $\begin{array}{c}\text { Individuals } \\
\text { without diabetes }\end{array}$ & $46-75$ & $\begin{array}{c}62 \\
\text { [Control:31 } \\
\text { \& Case: } 31]\end{array}$ & $\begin{array}{c}\text { T2DM } \\
(7.1 \pm 1.4) \\
(-)\end{array}$ & $\begin{array}{c}1.65 \\
(0.92,2.97)\end{array}$ & Age & $\begin{array}{l}\text { 13C or } \\
14 \mathrm{C} \text { urea } \\
\text { breath } \\
\text { test }\end{array}$ & 8 \\
\hline $\begin{array}{l}\text { Candelli, M. } \\
\text { et al(56) }\end{array}$ & 2003 & Italy & $\begin{array}{c}\text { The control } \\
\text { Group was } \\
\text { selected normal } \\
\text { healthy } \\
\text { adolescent }\end{array}$ & 17 & $\begin{array}{c}268 \\
\text { Control: } 147 \\
\text { \& Case: } \\
121)\end{array}$ & $\begin{array}{l}\text { T1DM }(8.2 \\
\pm 1.4) \\
(6.7 \text { Year })\end{array}$ & $\begin{array}{c}0.97 \\
(0.72,1.30)\end{array}$ & $\begin{array}{l}\text { Sex, age and } \\
\text { social class }\end{array}$ & $\begin{array}{c}\text { Rapid } \\
\text { urease } \\
\text { test, } \\
\text { Histology } \\
\text { or biopsy }\end{array}$ & 7 \\
\hline $\begin{array}{l}\text { Gulcelik, N. } \\
\text { E.et al (57) }\end{array}$ & 2005 & Turkey & $\begin{array}{c}\text { Dyspeptic non } \\
\text { diabetic subjects }\end{array}$ & 51.9 & $\begin{array}{c}149 \\
\text { [Control: } 71 \\
\text { \& Case: 78] }\end{array}$ & $\begin{array}{c}\text { T2DM } \\
(8.2 \pm 1.4)\end{array}$ & $\begin{array}{c}1.92 \\
(1.29,2.86)\end{array}$ & Age and BMI & $\begin{array}{l}\text { Histology } \\
\text { or biopsy }\end{array}$ & 7 \\
\hline $\begin{array}{l}\text { Jaber, S. } \\
\text { M.et al(58) }\end{array}$ & 2006 & $\begin{array}{l}\text { Saudi } \\
\text { Arabia }\end{array}$ & Healthy children & $>10$ & $\begin{array}{c}604 \\
\text { [Control:543 } \\
\text { \& Case: } 61]\end{array}$ & $\begin{array}{l}\text { T1DM } \\
(-) \\
(-)\end{array}$ & $\begin{array}{c}1.60 \\
(0.98,2.63)\end{array}$ & - & $\begin{array}{l}\text { Anti } \mathrm{H} . \\
\text { pylori } \\
\text { antibody }\end{array}$ & 6 \\
\hline $\begin{array}{l}\text { Bener, A. et } \\
\text { al(59) }\end{array}$ & 2007 & Qatar & $\begin{array}{l}\text { Non-diabetic } \\
\text { subjects }\end{array}$ & 48 & $\begin{array}{c}420 \\
\text { (Control:210 } \\
\text { \& Case: } \\
\text { 210) }\end{array}$ & $\begin{array}{c}\text { T2DM } \\
(6.9 \pm 1.4) \\
(-)\end{array}$ & $\begin{array}{c}5.03 \\
(3.90,6.47)\end{array}$ & Age and sex & $\begin{array}{l}\text { Anti-H. } \\
\text { pylori } \\
\text { antibody }\end{array}$ & 7 \\
\hline $\begin{array}{l}\text { Demir, M. et } \\
\text { al (60) }\end{array}$ & 2008 & Turkey & $\begin{array}{c}\text { The control } \\
\text { Subjects were } \\
\text { selected in the } \\
\text { gastroenterology } \\
\text { clinics }\end{array}$ & 52 & $\begin{array}{c}283 \\
\text { Control: } 142 \\
\text { \& Case: } 141\end{array}$ & $\begin{array}{c}\text { T2DM } \\
(-) \\
\text { (6 year) }\end{array}$ & $\begin{array}{c}1.07 \\
(0.84,1.36)\end{array}$ & Age and sex & $\begin{array}{c}\text { Rapid } \\
\text { urease } \\
\text { test and } \\
\text { Histology } \\
\text { or biopsy }\end{array}$ & 7 \\
\hline $\begin{array}{l}\text { Ariizumi, K. } \\
\text { et al(61) }\end{array}$ & 2008 & Japan & $\begin{array}{l}\text { non-diabetic } \\
\text { subjects without } \\
\text { upper GI tract } \\
\text { disorders }\end{array}$ & 62 & $\begin{array}{c}134 \\
\text { [Control: } 67 \\
\text { \& Case: 67] }\end{array}$ & $\begin{array}{c}\text { DM } \\
(-) \\
(15.1 \text { year })\end{array}$ & $\begin{array}{c}0.74 \\
(0.53,1.03)\end{array}$ & $\begin{array}{l}\text { age and sex- } \\
\text { matched }\end{array}$ & $\begin{array}{l}\text { Anti H. } \\
\text { pylori } \\
\text { antibody, } \\
\text { Rapid } \\
\text { urease } \\
\text { test, } \\
\text { Histology } \\
\text { or biopsy }\end{array}$ & 8 \\
\hline $\begin{array}{l}\text { Hamed, S. } \\
\text { A.et al(62) }\end{array}$ & 2008 & Egypt & $\begin{array}{c}\text { Subjects with } \\
\text { neither } \\
\text { history nor } \\
\text { clinical evidence } \\
\text { of } \\
\text { gastrointestinal } \\
\text { problems; } \\
\text { vascular, } \\
\text { inflammatory, or } \\
\text { neurologic } \\
\text { diseases. }\end{array}$ & 47.6 & $\begin{array}{c}140 \\
\text { [Control:60 } \\
\text { \& Case: } 80]\end{array}$ & $\begin{array}{c}\text { DM } \\
(-) \\
(9.2 \text { year })\end{array}$ & $\begin{array}{c}1.29 \\
(0.83,2.01)\end{array}$ & Age and sex & $\begin{array}{l}\text { Anti H. } \\
\text { pylori } \\
\text { antibody }\end{array}$ & 8 \\
\hline $\begin{array}{l}\text { Cabral, V. L. } \\
\text { R. et al(63) }\end{array}$ & 2009 & Brazil & $\begin{array}{c}\text { The control } \\
\text { Group was } \\
\text { selected normal } \\
\text { healthy } \\
\text { adolescent }\end{array}$ & 17 & $\begin{array}{c}45 \\
\text { Control: } 30 \\
\text { \& Case: } 15)\end{array}$ & $\begin{array}{c}\text { T1DM (-) } \\
(-)\end{array}$ & $\begin{array}{c}0.52 \\
(0.21,1.29)\end{array}$ & - & $\begin{array}{l}\text { Histology } \\
\text { or biopsy }\end{array}$ & 7 \\
\hline $\begin{array}{l}\text { Lazaraki, G. } \\
\text { et al (64) }\end{array}$ & 2009 & Greece & $\begin{array}{c}\text { non-smoking, } \\
\text { non-diabetic with } \\
\text { of dyspepsia }\end{array}$ & 65 & $\begin{array}{c}79 \\
\text { [Control: } 30 \\
\text { \& Case: 49] }\end{array}$ & $\begin{array}{c}\text { T2DM } \\
(-) \\
\text { (3 year) }\end{array}$ & $\begin{array}{c}0.99 \\
(0.70,1.40)\end{array}$ & $\begin{array}{c}\text { Age, sex, H. } \\
\text { pylori- } \\
\text { infection, } \\
\text { degree of } \\
\text { gastritis }\end{array}$ & $\begin{array}{c}\text { Rapid } \\
\text { urease } \\
\text { test and } \\
\text { Histology } \\
\text { or biopsy }\end{array}$ & 7 \\
\hline $\begin{array}{l}\text { Krause, I. et } \\
\text { al (65) }\end{array}$ & 2009 & Colombia & Individuals had & 16.0 & 180 & T1DM & 0.44 & - & Anti-H. & 6 \\
\hline
\end{tabular}




\begin{tabular}{|c|c|c|c|c|c|c|c|c|c|c|}
\hline & & & $\begin{array}{c}\text { no clinical } \\
\text { diabetes, nor } \\
\text { islet cell } \\
\text { autoantibodies }\end{array}$ & & $\begin{array}{l}\text { [Control123: } \\
\text { \& Case: 57] }\end{array}$ & $\begin{array}{c}(-) \\
(8.8 \text { year })\end{array}$ & $(0.29,0.66)$ & & $\begin{array}{c}\text { pylori } \\
\text { antibody }\end{array}$ & \\
\hline $\begin{array}{l}\text { Devrajani, } \\
\text { BR. et al } \\
\text { (66) }\end{array}$ & 2010 & Pakistan & $\begin{array}{l}\text { Non diabetic } \\
\text { individuals with } \\
\text { positive or } \\
\text { negative } \\
\text { Helicobacter } \\
\text { pylori infection }\end{array}$ & 53 & $\begin{array}{c}148 \\
\text { [Control: } 74 \\
\text { \& Case: } 74]\end{array}$ & $\begin{array}{c}\text { T2DM } \\
(-) \\
\text { (5 years) }\end{array}$ & $\begin{array}{c}1.64 \\
(1.11,2.43)\end{array}$ & - & $\begin{array}{l}\text { Stool } \\
\text { antigen } \\
\text { test }\end{array}$ & 7 \\
\hline $\begin{array}{l}\text { Ibrahim, A. } \\
\text { et al(67) }\end{array}$ & 2010 & Egypt & $\begin{array}{l}\text { Dyspeptic non } \\
\text { diabetic subjects }\end{array}$ & 45 & $\begin{array}{c}200 \\
\text { [Control: } \\
102 \text { \& Case: } \\
98]\end{array}$ & $\begin{array}{l}\text { T2DM } \\
(8.57 \pm \\
0.79) \\
(-)\end{array}$ & $\begin{array}{c}0.94 \\
(0.71,1.25)\end{array}$ & - & $\begin{array}{c}\text { Rapid } \\
\text { urease } \\
\text { test, } \\
\text { Histology } \\
\text { or biopsy }\end{array}$ & 7 \\
\hline $\begin{array}{l}\text { El-Eshmawy, } \\
\text { M. M. et } \\
\text { al(68) }\end{array}$ & 2011 & Egypt & $\begin{array}{l}\text { Non-diabetic } \\
\text { subjects }\end{array}$ & 20 & $\begin{array}{c}242 \\
\text { (Control:80 } \\
\text { \& Case: } \\
162)\end{array}$ & $\begin{array}{c}\text { T1DM } \\
(8.2 \pm 1.75) \\
(7.29 \text { Year })\end{array}$ & $\begin{array}{c}1.63 \\
(1.25,2.11)\end{array}$ & $\begin{array}{c}\text { Age, sex, } \\
\text { geographic } \\
\text { area and } \\
\text { socioeconomic } \\
\text { status } \\
\end{array}$ & $\begin{array}{l}\text { Anti-H. } \\
\text { pylori } \\
\text { antibody }\end{array}$ & 7 \\
\hline $\begin{array}{c}\text { De Block, C. } \\
\text { E. M. et } \\
\text { al(69) }\end{array}$ & 2012 & Belgium & $\begin{array}{l}\text { One-hundred } \\
\text { sex- and age- } \\
\text { matched } \\
\text { controls } \\
\text { were tested for } \\
\text { H. pylori } \\
\text { serology. }\end{array}$ & 40 & $\begin{array}{c}329 \\
\text { Control: } 100 \\
\text { \& Case: } \\
\text { 229) }\end{array}$ & $\begin{array}{l}\text { T1DM }(7.8 \\
\pm 1.0) \\
\text { (18 Year) }\end{array}$ & $\begin{array}{c}0.86 \\
(0.74,1.02)\end{array}$ & Age and sex & $\begin{array}{c}\text { Anti-H. } \\
\text { pylori } \\
\text { antibody } \\
\& \\
\text { Rapid } \\
\text { urease } \\
\text { test and } \\
\text { Histology } \\
\text { or biopsy }\end{array}$ & 7 \\
\hline $\begin{array}{l}\text { Candelli, M. } \\
\text { et al (70) }\end{array}$ & 2012 & Italy & Healthy children & 19.8 & $\begin{array}{c}174 \\
\text { [Control: } 99 \\
\text { \& Case: } 75]\end{array}$ & $\begin{array}{c}\text { T1DM } \\
(8.8 \pm 0.80) \\
(-)\end{array}$ & $\begin{array}{c}1.96 \\
(1.40,2.75)\end{array}$ & $\begin{array}{c}\text { Age, sex and } \\
\text { socio- } \\
\text { economic }\end{array}$ & $\begin{array}{l}\text { 13C or } \\
\text { 14C urea } \\
\text { breath } \\
\text { test }\end{array}$ & 6 \\
\hline $\begin{array}{l}\text { Jafarzadeh, } \\
\text { A.et al (71) }\end{array}$ & 2012 & Iran & $\begin{array}{c}\text { Healthy } \\
\text { individuals }\end{array}$ & 42.86 & $\begin{array}{c}200 \\
\text { [Control: } \\
100 \text { \& Case: } \\
100]\end{array}$ & $\begin{array}{c}\text { T2DM } \\
(-) \\
(-)\end{array}$ & $\begin{array}{c}1.03 \\
(0.74,1.42)\end{array}$ & Age & $\begin{array}{c}\text { Anti } \mathrm{H} . \\
\text { pylori IgG }\end{array}$ & 6 \\
\hline $\begin{array}{l}\text { Keramat, F. } \\
\text { et al( } 72)\end{array}$ & 2013 & Iran & $\begin{array}{l}\text { Non-diabetic } \\
\text { subjects }\end{array}$ & 51 & $\begin{array}{c}158 \\
\text { (Control: } 79 \\
\text { \& Case: } 79 \text { ) }\end{array}$ & $\begin{array}{c}\mathrm{DM}(8.96 \pm \\
1.82) \\
(2.78 \text { Year })\end{array}$ & $\begin{array}{c}1.29 \\
(0.89,1.88)\end{array}$ & Age and sex & $\begin{array}{c}\text { Anti-H. } \\
\text { pylori } \\
\text { antibody } \\
\& \\
\text { Rapid } \\
\text { urease } \\
\text { test and } \\
\text { Histology } \\
\text { or biopsy }\end{array}$ & 8 \\
\hline $\begin{array}{l}\text { Zekry, O. A. } \\
\text { et al(73) }\end{array}$ & 2013 & Egypt & $\begin{array}{l}\text { Healthy children } \\
\text { and adolescents }\end{array}$ & 12.53 & $\begin{array}{c}120 \\
\text { [Control: } 60 \\
\text { \& Case: 60] }\end{array}$ & $\begin{array}{c}\text { T1DM } \\
(7.75 \pm 1.67) \\
\text { (9.25 year) }\end{array}$ & $\begin{array}{c}1.69 \\
(1.21,2.35)\end{array}$ & Age and sex & $\begin{array}{l}\text { Anti-H. } \\
\text { pylori } \\
\text { antibody }\end{array}$ & 8 \\
\hline $\begin{array}{l}\text { Chobot, A. et } \\
\text { al(74) }\end{array}$ & 2014 & Poland & $\begin{array}{l}\text { This group was } \\
\text { enrolled from a } \\
\text { large cohort of } \\
\text { children }\end{array}$ & 13.4 & $\begin{array}{c}447 \\
\text { [Control: } \\
298 \text { \& Case: } \\
149]\end{array}$ & $\begin{array}{c}\text { T1DM } \\
(7.69 \pm \\
1.63) \\
\text { (4.6 year) }\end{array}$ & $\begin{array}{c}0.74 \\
(0.48,1.15)\end{array}$ & Age- and sex & $\begin{array}{l}13 \mathrm{C} \text { or } \\
14 \mathrm{C} \text { urea } \\
\text { breath } \\
\text { test }\end{array}$ & 8 \\
\hline $\begin{array}{l}\text { Fayed, SB. } \\
\text { et al(75) }\end{array}$ & 2014 & Egypt & $\begin{array}{l}\text { healthy normal } \\
\text { volunteers }\end{array}$ & 12.2 & $\begin{array}{c}106 \\
\text { [Control:53 } \\
\text { \& Case: 53] }\end{array}$ & $\begin{array}{c}\text { T1DM } \\
(9.6 \pm 1.6) \\
(12.2 \text { year })\end{array}$ & $\begin{array}{c}1.80 \\
(1.14,2.84)\end{array}$ & Age and sex & $\begin{array}{c}\text { Anti H. } \\
\text { pylori } \\
\text { antibodies }\end{array}$ & 7 \\
\hline $\begin{array}{l}\text { Zhou, F. et } \\
\text { al(17) }\end{array}$ & 2015 & China & $\begin{array}{l}\text { Non-diabetic } \\
\text { subjects with } \\
\text { dyspepsia } \\
\text { symptoms }\end{array}$ & 45 & $\begin{array}{c}253 \\
\text { (Control:65 } \\
\text { \& Case: } \\
188)\end{array}$ & $\begin{array}{c}\mathrm{T} 2 \mathrm{DM} \\
(8.2 \pm 1.9)\end{array}$ & $\begin{array}{c}1.15 \\
(0.99,1.33)\end{array}$ & Age and sex & $\begin{array}{l}\text { Anti-H. } \\
\text { pylori } \\
\text { antibody } \\
\& \\
\text { Rapid } \\
\text { urease } \\
\text { test }\end{array}$ & 9 \\
\hline Bajaj, S. et & 2015 & India & The control & $>18$ & 140 & T2DM (8.2 & 1.53 & Age, sex, & Anti-H. & 8 \\
\hline
\end{tabular}




\begin{tabular}{|c|c|c|c|c|c|c|c|c|c|c|}
\hline al(3) & & & $\begin{array}{l}\text { group comprised } \\
\text { of age, sex, } \\
\text { socioeconomic } \\
\text { status, and } \\
\text { education } \\
\text { matched normal } \\
\text { healthy } \\
\text { volunteers }\end{array}$ & & $\begin{array}{l}\text { Control: } 60 \\
\text { \& Case: } 80 \text { ) }\end{array}$ & $\begin{array}{c} \pm 1.2) \\
(4.2 \text { Year })\end{array}$ & $(1.04,2.24)$ & $\begin{array}{l}\text { socioeconomic } \\
\text { status, and } \\
\text { education }\end{array}$ & $\begin{array}{c}\text { pylori } \\
\text { antibody } \\
\& \\
\text { Rapid } \\
\text { urease } \\
\text { test and } \\
\text { Histology } \\
\text { or biopsy }\end{array}$ & \\
\hline $\begin{array}{c}\text { Bazmamoun, } \\
\text { H. et al(76) }\end{array}$ & 2016 & Iran & $\begin{array}{l}\text { Non-diabetic } \\
\text { subjects }\end{array}$ & 10 & $\begin{array}{c}160 \\
\text { (Control: } 80 \\
\text { \& Case: } 80 \text { ) }\end{array}$ & $\begin{array}{c}\text { T1DM (8.00 } \\
\pm 0.65) \\
(2.72 \text { Year })\end{array}$ & $\begin{array}{c}1.50 \\
(1.09,2.07)\end{array}$ & $\begin{array}{c}\text { Age, sex, } \\
\text { socioeconomic } \\
\text { status }\end{array}$ & $\begin{array}{c}\text { Anti-H. } \\
\text { pylori } \\
\text { antibody }\end{array}$ & 8 \\
\hline $\begin{array}{l}\text { Osman, S. } \\
\text { M.et al(77) }\end{array}$ & 2016 & Sudan & Healthy children & $1-18$ & $\begin{array}{c}180 \\
\text { [Control: } 90 \\
\text { \& Case: } 90]\end{array}$ & $\begin{array}{c}\text { T1DM } \\
(-) \\
\text { (6 month) }\end{array}$ & $\begin{array}{c}0.97 \\
(0.71,1.33)\end{array}$ & age and sex & $\begin{array}{c}\text { Anti-H. } \\
\text { pylori } \\
\text { antibody }\end{array}$ & 8 \\
\hline $\begin{array}{l}\text { Alzahrani, S. } \\
\text { et al(78) }\end{array}$ & 2017 & $\begin{array}{l}\text { Saudi } \\
\text { Arabia }\end{array}$ & $\begin{array}{l}\text { Non-diabetic } \\
\text { subjects }\end{array}$ & 49 & $\begin{array}{c}842 \\
\text { (Control:421 } \\
\text { \& Case: } \\
\text { 421) }\end{array}$ & $\begin{array}{l}\mathrm{DM}(6.1 \pm \\
0.6)\end{array}$ & $\begin{array}{c}1.01 \\
(0.88,1.16)\end{array}$ & $\begin{array}{c}\text { Age, } \\
\text { sex, race, } \\
\text { DPP } \\
\text { intervention, } \\
\text { length of } \\
\text { follow-up } \\
\text { time, body } \\
\text { mass index, } \\
\text { alcohol } \\
\text { consumption, } \\
\text { physical } \\
\text { activity and } \\
\text { smoking }\end{array}$ & $\begin{array}{c}\text { Anti-H. } \\
\text { pylori } \\
\text { antibody } \\
\& \\
\text { Rapid } \\
\text { urease } \\
\text { test }\end{array}$ & 9 \\
\hline $\begin{array}{l}\text { Vaishnav, B. } \\
\text { et al (79) }\end{array}$ & 2018 & India & $\begin{array}{c}\text { Non diabetic } \\
\text { with dyspepsia }\end{array}$ & 56 & $\begin{array}{c}287 \\
\text { [Control: } \\
140 \text { \& Case: } \\
147]\end{array}$ & $\begin{array}{c}\text { T2DM } \\
(8.4 \pm 1.0) \\
(7.59 \text { year })\end{array}$ & $\begin{array}{c}1.89 \\
(1.51,2.36)\end{array}$ & - & $\begin{array}{c}\text { Rapid } \\
\text { urease } \\
\text { test }\end{array}$ & 8 \\
\hline
\end{tabular}

Table 2: Summary odds Ratio (OR) Estimates [95 \% confidence intervals (CIs)] for Case-Control studies Conducted on the Association Between Helicobacter pylori and Risk of diabetes by Type of diabetes, Continent, Mean of HbA1C, Duration of Diabetes, Method of detection bacteria, NOS score and Age. 


\begin{tabular}{|c|c|c|c|c|c|c|c|}
\hline \multirow[t]{2}{*}{ Subgroup } & \multirow[t]{2}{*}{$\begin{array}{l}\text { Number of } \\
\text { studies }\end{array}$} & \multirow[t]{2}{*}{$\begin{array}{c}\text { Summery Odds Ratio } \\
(95 \% \mathrm{CI})\end{array}$} & \multicolumn{3}{|c|}{ Between studies } & \multicolumn{2}{|c|}{$\begin{array}{c}\text { Between } \\
\text { subgroups }\end{array}$} \\
\hline & & & $\mathrm{I}^{2}$ & \begin{tabular}{|c|}
$\mathrm{P}$ \\
heterogeneity \\
\end{tabular} & $\mathrm{Q}$ & $\mathrm{Q}$ & $\begin{array}{c}\mathrm{P} \\
\text { heterogeneity }\end{array}$ \\
\hline $\begin{array}{l}\text { Type of diabetes } \\
\text { Diabetes Mellitus } \\
\text { Type } 1 \text { Diabetes } \\
\text { Type } 2 \text { Diabetes }\end{array}$ & $\begin{array}{l}11 \\
15 \\
15\end{array}$ & $\begin{array}{l}1.17(0.94-1.45) \\
1.19(0.98-1.45) \\
1.43(1.11-1.85)\end{array}$ & $\begin{array}{c}82.5 \\
\% \\
81.6 \\
\% \\
90.0 \\
\%\end{array}$ & $\begin{array}{l}0.0001 \\
0.0001 \\
0.0001\end{array}$ & $\begin{array}{l}1.43 \\
1.75 \\
2.72\end{array}$ & 3.59 & 0.0001 \\
\hline $\begin{array}{l}\text { Continent } \\
\text { Asian } \\
\text { American } \\
\text { African } \\
\text { European }\end{array}$ & $\begin{array}{c}12 \\
2 \\
7 \\
20\end{array}$ & $\begin{array}{l}1.41(1.05-1.88) \\
0.45(0.31-0.66) \\
1.32(1.05-1.66) \\
1.26(1.08-1.47)\end{array}$ & \begin{tabular}{|c|}
$93.2 \%$ \\
$0.0 \%$ \\
$61.0 \%$ \\
$80.3 \%$
\end{tabular} & $\begin{array}{c}0.0001 \\
0.728 \\
0.018 \\
0.0001\end{array}$ & $\begin{array}{l}2.29 \\
4.12 \\
2.40 \\
2.94\end{array}$ & 3.59 & 0.001 \\
\hline $\begin{array}{c}\text { Mean of } \mathrm{HbA} 1 \mathrm{C}^{*} \\
6-8 \\
8<\end{array}$ & $\begin{array}{c}9 \\
13\end{array}$ & $\begin{array}{l}1.40(0.92-2.13) \\
1.41(1.20-1.64)\end{array}$ & $\begin{array}{c}95.0 \\
\% \\
73.7 \\
\%\end{array}$ & $\begin{array}{l}0.001 \\
0.001\end{array}$ & $\begin{array}{l}1.55 \\
4.33\end{array}$ & 3.59 & 0.0001 \\
\hline $\begin{array}{c}\text { Duration of Diabetes* } \\
0-3 \mathrm{Y} \\
4-7 \mathrm{Y} \\
8<\mathrm{Y}\end{array}$ & $\begin{array}{c}7 \\
10 \\
9\end{array}$ & $\begin{array}{l}1.18(1.06-1.31) \\
1.15(0.95-1.38) \\
1.09(0.79-1.51)\end{array}$ & \begin{tabular}{|l|}
$0.0 \%$ \\
69.1 \\
$\%$ \\
91.0 \\
$\%$ \\
\end{tabular} & $\begin{array}{c}0.450 \\
0.001 \\
0.0001\end{array}$ & $\begin{array}{l}3.07 \\
1.45 \\
0.55\end{array}$ & 3.59 & 0.001 \\
\hline $\begin{array}{c}\text { Method of detection bacteria } \\
\text { Anti-H. pylori antibody \& Rapid urease test } \\
\text { Histology or biopsy } \\
\text { Anti-H. pylori antibody } \\
\text { Anti-H. pylori antibody \& Rapid urease test \& } \\
\text { Histology or biopsy } \\
\text { Rapid urease test \& Histology or biopsy } \\
\text { 13C or 14C urea breath test } \\
\text { Rapid urease test } \\
\text { Stool antigen test }\end{array}$ & $\begin{array}{c}2 \\
6 \\
14 \\
4 \\
\\
5 \\
6 \\
3 \\
1\end{array}$ & $\begin{array}{c}1.08(0.95-1.22) \\
1.04(0.58-1.84) \\
1.40(1.07-1.85) \\
1.03(0.76-1.40) \\
1.06(0.91-1.23) \\
1.27(0.94-1.72) \\
1.73(0.93-3.23) \\
-\end{array}$ & \begin{tabular}{|l|}
35.0 \\
$\%$ \\
85.0 \\
$\%$ \\
91.2 \\
$\%$ \\
76.0 \\
$\%$ \\
\\
18.3 \\
$\%$ \\
73.4 \\
$\%$ \\
91.3 \\
$\%$ \\
-
\end{tabular} & $\begin{array}{c}0.215 \\
0.0001 \\
0.0001 \\
0.006 \\
\\
0.298 \\
0.002 \\
0.0001 \\
-\end{array}$ & $\begin{array}{l}1.14 \\
0.12 \\
2.44 \\
0.21 \\
\\
0.74 \\
1.56 \\
2.49 \\
-\end{array}$ & 3.59 & 0.0001 \\
\hline $\begin{array}{c}\text { Age* } \\
10-30 \mathrm{Y} \\
30-60 \mathrm{Y} \\
60<\mathrm{Y}\end{array}$ & $\begin{array}{c}15 \\
18 \\
3\end{array}$ & $\begin{array}{l}1.30(1.05-1.62) \\
1.34(1.09-1.65) \\
1.03(0.68-1.57)\end{array}$ & \begin{tabular}{|l|}
81.9 \\
$\%$ \\
91.3 \\
$\%$ \\
76.4 \\
$\%$ \\
\end{tabular} & $\begin{array}{c}0.0001 \\
0.0001 \\
0.014\end{array}$ & $\begin{array}{l}2.37 \\
2.77 \\
0.15\end{array}$ & 3.59 & 0.0001 \\
\hline $\begin{array}{c}\text { NOS Score } \\
6 \\
7 \\
8 \\
9\end{array}$ & $\begin{array}{c}11 \\
16 \\
12 \\
2\end{array}$ & $\begin{array}{l}1.14(0.85-1.53) \\
1.42(1.10-1.82) \\
1.24(1.00-1.53) \\
1.08(0.95-1.22)\end{array}$ & \begin{tabular}{|l|}
87.7 \\
$\%$ \\
89.0 \\
$\%$ \\
81.6 \\
$\%$ \\
35.0 \\
$\%$
\end{tabular} & $\begin{array}{c}0.0001 \\
0.0001 \\
0.0001 \\
0.216\end{array}$ & $\begin{array}{l}0.86 \\
2.72 \\
1.96 \\
1.14\end{array}$ & 3.59 & 0.0001 \\
\hline
\end{tabular}

Largely diabetes mellitus

All statistical tests were 2-sided.

*other studies not reported HbA1C, duration of diabetes, 


\section{Figures}

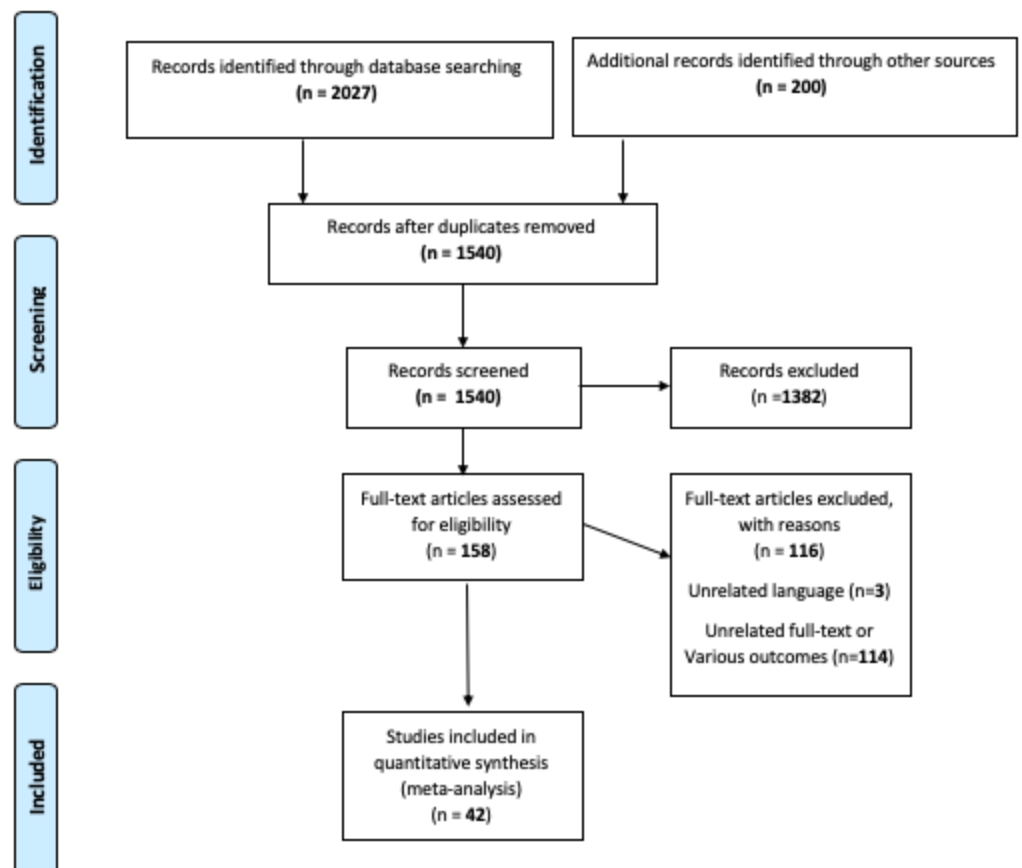

Figure 1

Flow Diagram of the Literature Search and Study Selection

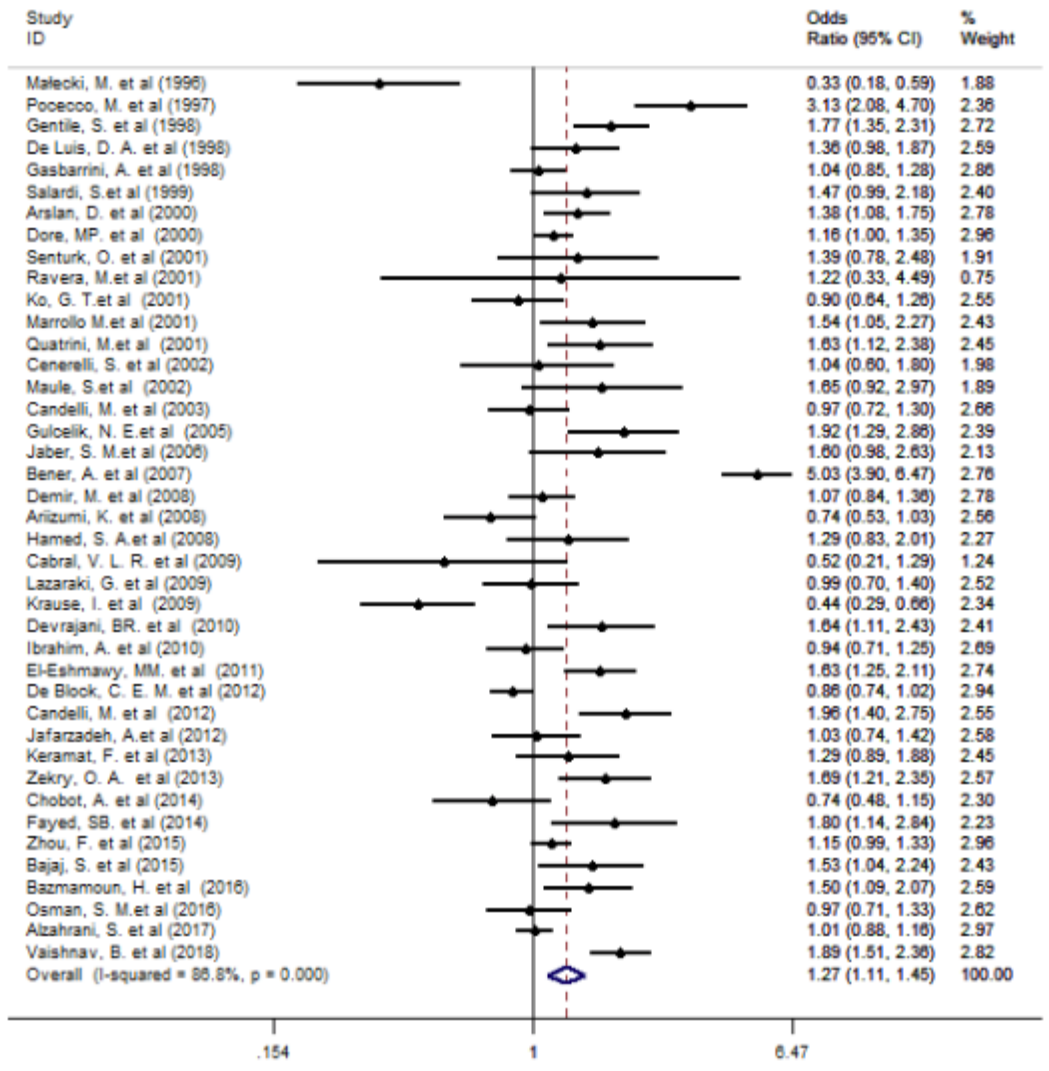

Figure 2 
Association between Helicobacter pylori and Risk of diabetes (DM, T2DM and T1DM)

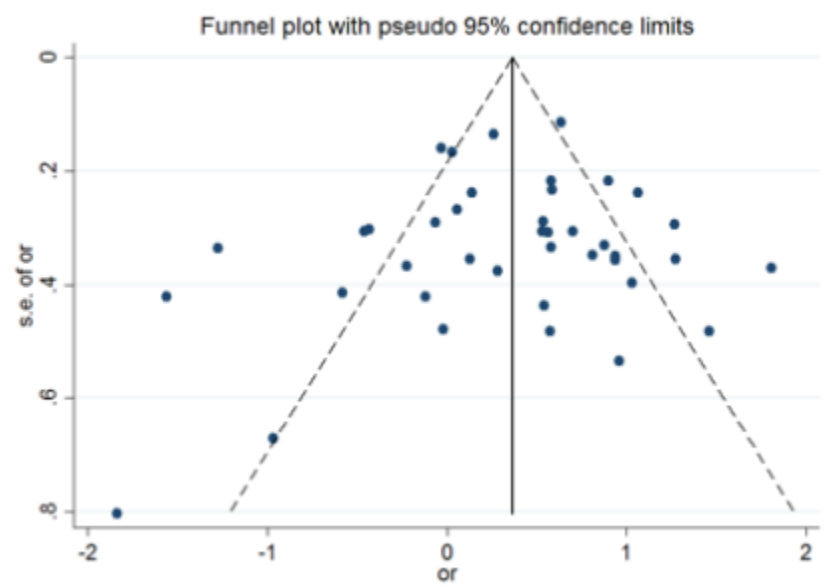

\section{Figure 3}

Funnel plot of association between Helicobacter pylori and Risk of diabetes 